GLOBAL JOURNAL OF AGRICULTURAL SCIENCES VOL. 14, 2015: 1-9 COPYRIGHT@ BACHUDO SCIENCE CO. LTD PRINTED IN NIGERIA ISSN 1596-2903

\title{
EFFECT OF TIME OF FERTILIZER APPLICATION ON GROWTH AND YIELD OF MAIZE (ZEA MAYS L.) IN JOS - PLATEAU ENVIRONMENT
}

\author{
PRECIOUS E. AMALI AND O. A. T. NAMO
}

(Received 14 September 2013; Revision Accepted 10 April 2014)

\begin{abstract}
An experiment was carried out during the 2006 growing season, between June and November, to investigate the growth and yield responses of four varieties of maize (SUWAN-1-Y, TZSR-Y, DMESR-W and ACROSS-97 TZL) to time of fertilizer application (2,4 and 6 weeks after planting). The experiment was laid out in a $3 \times 4$ factorial in a randomized complete block design with four replications. The results indicated that the mean number of leaves per plant, leaf area index (LAl), plant height, mean number of rows per ear, ear weight, shelling \%, kernel weight and total grain yield significantly $(P<0.05)$ increased when fertilizer was applied at two weeks after planting. The mean number of days to $50 \%$ tasseling and $50 \%$ silking decreased when fertilizer was applied at six weeks after planting. The mean number of barren plants increased with delay in fertilizer application at six weeks after planting. The interactions of variety and time of fertilizer application on the number of rows per ear, mean ear weight, kernel weight and shelling $\%$ were significant. The study revealed that the yield of maize could be enhanced by the early application of fertilizer at two weeks after planting. These results are discussed in the light of time of fertilizer application on growth and yield attributes of maize.
\end{abstract}

KEYWORDS: Fertilizer, Growth, Yield, Zea mays L.

\section{INTRODUCTION}

Maize (Zea mays (L.) is the oldest and widely cultivated cereal in the world. It requires adequate soil fertility for growth and high grain yield. According to Kolawole and Joyce (2009), the low fertility status of most tropical soils hinders maize production as it has a strong exhausting effect on the soil. Adediran and Banjoko (2003) observed that maize failed to produce high grain yield in plots without adequate nutrition. Stefano et al. (2004) reported that inorganic fertilizer applications exerted a strong influence on growth, development and grain yield of maize. Fashina et al. (2002) and Obi et al. (2005) observed that the availability of sufficient growth nutrients resulted in improved cell activities, enhanced cell multiplication, enlargement and luxuriant growth as well as high dry matter production. Adediran and Banjoko (2003) reported that there was decreased grain yield resulting from low application of NPK fertilizer.

Lucy et al. (1998) noted that the type of crop influences the timing and frequency of fertilizer application since some crops are heavier feeders of particular nutrients than the others. It has been reported that maize is a heavy feeder of nitrogen and that it requires nitrogen application at four weeks after planting Lucy et al. (1998). AERLS (1987) reported that about $333 \mathrm{~kg} \mathrm{ha}^{-1}$ of compound fertilizer should be applied at planting time, followed by top dressing with calcium ammonium nitrate (CAN) six weeks later. For hybrid maize, $400 \mathrm{~kg} \mathrm{ha}^{-1}$ of
NPK is recommended to be applied just before planting, which should be followed up four weeks after planting with $250 \mathrm{~kg} \mathrm{ha}^{-1}$ of CAN as side- dressing.

Kolawole and Joyce (2009) in Benin city conducted a research and the result of experiment indicated that the number of leaves per plant and leaf area increased at 4, 6 and 8 WAP when fertilizer was applied to the maize plant at the rate of $600 \mathrm{~kg} \mathrm{NPK} \mathrm{ha}{ }^{-1}$. They also found a significant correlation in the number of leaves with fertilizer rate at 6 WAP $(r=0.72)$ and at 8 WAP $(r=0.60)$. Stefano et al. (2001) also reported that fertilizer application resulted in luxuriant growth.

According to Olaoye and Adegbesen (1991), the International Centre for Maize and Wheat Improvement Mexico (CIMMYT) reported that maize yield in West Africa has stagnated at about $1 \mathrm{tha}^{-1}$ as compared to the global average yield of 2.2-3.5 $\mathrm{t} \mathrm{ha}^{-1}$. Idachaba (1994) reported that the low productivity per unit land area has made Nigeria one of the non-competitive producers of maize in the world. In this light, farmers have to rely heavily on the use of inorganic fertilizers to supplement available soil nutrients. However, the high cost of these fertilizers has made the commodity scarce and unaffordable by the local farmers. Consequently, they are unable to procure and apply the fertilizers as at when needed. Information is presently lacking on the decline in yield as a result of delay in fertilizer application on maize. This study was therefore, aimed at investigating the effect of delay in fertilizer application on the growth and yield of four

Precious E. Amali, Department of Plant Science and Technology, University of Jos, Jos, Nigeria.

O. A. T. Namo, Department of Plant Science and Technology, University of Jos, Jos, Nigeria. 
commonly cultivated hybrid varieties of maize in the Jos Plateau environment of Nigeria.

\section{MATERIALS AND METHODS}

The study was carried out at the Federal College of Forestry, Jos $\left(09^{\circ} 57^{1} \mathrm{~N}\right.$; $08^{0} 53^{1} \mathrm{E} ; 1,159 \mathrm{~m}$ above sealevel). The experiment was laid out in a $3 \times 4$ factorial, in a Randomized Complete Block Design with four replications, comprising three intervals of fertilizer application (2, 4 and 6 weeks after planting) and four varieties of maize (SUWAN-I-Y, TZSR-Y, DMESR-W and ACROSS-97 TZL). The size of a plot per treatment was $2 \times 1.6 \mathrm{~m}^{2}$, consisting of two $0.8 \mathrm{~m}$ ridges, each measuring 2 meters long. A path of $0.5 \mathrm{~m}$ was left between replicates.

\section{SITE PREPARATION}

The Land was cleared, stumped, gathered and removed. Ridging was done manually, using the West African hoe. Three (3) seeds per hill were planted at a spacing of $1.0 \mathrm{~m} \times 0.2 \mathrm{~m}$. Seedlings were later thinned to one plant per hill, giving a total of 62,500 plants per hectare. Thinning was done before the application of fertilizer.

Elemental nitrogen, phosphorus and potassium were obtained from urea, single superphosphate and muriate of potash $\left(\mathrm{P}_{2} \mathrm{O}_{4}\right)$, respectively. Nitrogen was supplied at the rate of $120 \mathrm{~kg} \mathrm{ha}^{-1}$, which was equivalent to $83.4 \mathrm{~g}$ of urea per plot. Phosphorus was applied at the rate of $200 \mathrm{~kg} \mathrm{ha}{ }^{-1}$, equivalent of $335.6 \mathrm{~g}$ of single superphosphate per plot, while potassium was applied at the rate of $50 \mathrm{~kg} \mathrm{ha}^{-1}$ of muriate of potash or $26.6 \mathrm{~g}$ of KCl per plot. The fertilizers were applied at 14, 28 and 42 DAP or 2, 4 and 6 weeks after planting, respectively. Weeding was done manually with a hoe at 2 WAP and subsequently as the need arose. The plots were earthened at 80 DAP to prevent the exposure of roots by erosion and lodging. Army worms (Spodoptera littoralis) were controlled by spraying with Karate (lambda cyhalothrin) at the rate of $50 \mathrm{ml}$ per 20 litres of water, three weeks after planting.

The parameters measured included number of leaves per plant, leaf area index, mid-tasselling, midsilking, plant height, number of barren plants per plot, number of ears per plant, number of rows per ear, mean ear weight, shelling percentage, one thousand kernel weight and total grain yield.

\section{DETERMINATION OF FIELD PARAMETERS}

Mean number of leaves per plant: Five plants were tagged in each plot, the number of number of leaves of each of which was counted. This was divided by the number of plants tagged to give the mean number of leaves per plant.

Leaf area (LA): From each of the five plants tagged in each plot, the length and width of two leaves were measured using a measuring tape. Measurement was from the tip of the leaf to the leaf base. Leaf area was computed by multiplying the mean length by the mean width and by 0.75 (Egharevba et al., 1976). Total leaf area was obtained by summing up the leaf area over all the leaves in the plot (Watson, 1947).

Leaf area index (LAI): Leaf area index was calculated by dividing the total leaf area by the land area occupied by the sampled plant

$\mathrm{LAI}=\frac{\mathrm{LA}}{\text { Land area }}$

Mid-tasseling: The number of days to mid-tasselling was recorded as the number of days from planting to when at least $50 \%$ of the total plant stands within the plot had tasselled.

Mid-silking: The number of days to mid-silking was recorded as the number of days from planting to when at least $50 \%$ of the total plant stands within the plot had silked.

Plant height (cm): At harvest (145 days after planting), five plants were tagged in each plot. The height of each of the plants was measured from the base to the flag leaf. The mean plant height was used for the statistical analysis.

Number of sterile plants: Five plants were tagged in each plot at harvest (145 DAP). The total number of sterile plants in each plot was counted and divided by the total number of plants in the respective plots to give the mean number of sterile plants per plot.

Mean number of ears per plant: The total number of ears in each plot was counted and divided by the number of plants in the respective plots to give the mean number of ears per plant.

Ear length (cm): Five ears were tagged in each plot, the length of each of which measured from the base to the tip, using a measuring tape. The mean ear length was used for the statistical analysis.

Ear width (cm): The diameter of each of the five tagged ears per plot was measured at the widest portion and divided by five to give the mean ear width.

Number of rows per ear: Five ears were tagged in each plot and the number of rows in each ear was counted and divided by the number of ears to obtain the mean number of rows per ear.

Ear weight (g): Five ears were tagged in each plot, each of which was weighed. The weight was divided by five to give the mean ear weight which was used for the statistical analysis.

Number of kernels per row: The number of kernels was counted in each of two rows in each of the five tagged ears in each plot. The mean was used for the statistical analysis. 
Shelling percentage: Five ears were tagged in each plot and weighed. The five ears were shelled and the grains were weighed. The shelling percentage was computed by dividing the weight of the grains alone by the weight of the grains plus the cobs and multiplying by 100 (Awotundun et al., 1994), as follows:

Shelling $\%=\mathrm{b} / \mathrm{a} \times 100$

Where,

$$
\begin{aligned}
& a=\text { weight of cob }+ \text { grains } \\
& b=\text { weight of grains alone }
\end{aligned}
$$

Weight of one thousand kernels $(g)$ : One thousand kernels were sampled from the whole grain lot per plot and weighed.

Total grain yield $\left(\mathbf{t} \mathbf{~ h a}^{-1}\right)$ : Total grain was computed at $13 \%$ moisture content (safe storage moisture content of maize, according to AERLS, 1987). The whole grain harvested in each plot was weighed and the weight was converted to the equivalent weight at $13 \%$ moisture content and then to tonnes per hectare before the statistical analysis.

\section{DATA ANALYSIS}

Data collected were subjected to a two-way analysis of variance test and means were compared using the least significant difference (LSD) at $5 \%$ level of probability (Fasina, 2000).

\section{RESULTS}

Number of leaf blades per plant: The number of leaf blades per plant increased with crop age up to 88 days after planting (88 DAP) and thereafter decreased in the varieties SUWAN-I-Y and ACROSS -97 TZL. In the varieties TZSR-Y and DMESR-W, however, the number of leaf blades increased with crop age throughout the sampling period (Table 1). Differences in the number of leaf blades per plant with respect to the time of fertilizer application were not significant $\quad(P<0.05)$.

Table 1: Effects of variety and time of fertilizer application on number of leaf blades per plant at different stages of growth of maize during the 2006 planting season

\begin{tabular}{|c|c|c|c|c|c|c|c|}
\hline & 53 & 60 & 67 & 74 & 81 & 88 & 95 \\
\hline SUWAN-1-Y & 10.07 & 9.15 & 9.80 & 11.15 & 11.33 & 11.35 & 11.02 \\
\hline TZSR-Y & 9.42 & 8,78 & 9.30 & 10.78 & 11.65 & 10.98 & 11.23 \\
\hline DMESR-W- & 9.20 & 8.75 & 9.50 & 10.93 & 10.83 & 10.72 & 10.28 \\
\hline AGROSS-97 TZL & 10.08 & 9.00 & 10.00 & 11.50 & 11.30 & 11. 27 & 11.35 \\
\hline $\operatorname{LSD}(0.05)$ & 0.93 & 0.87 & 0.81 & 1.03 & 0.83 & 1.12 & 0.83 \\
\hline $\begin{array}{l}\text { Appl. Time }(W A P)^{*} \\
2\end{array}$ & 10.52 & 8.79 & 9.35 & 10.58 & 10.09 & 11.13 & 10.89 \\
\hline 4 & 9.58 & 8.70 & 9.70 & 11.48 & 11.78 & 11.00 & 11.39 \\
\hline 6 & 9.40 & 9.28 & 9.95 & 11.23 & 11.01 & 10.79 & 10.64 \\
\hline $\operatorname{LSD}(0.05)$ & 0.81 & 0.72 & 0.69 & 0.90 & 0.72 & 0.96 & 0.72 \\
\hline
\end{tabular}

\section{VARIETY DAYS AFTER PLANTING}

Leaf area index (LAI): The leaf area index increased with crop age up to 81 days after planting (81 DAP) in all but the variety ACROSS-97 TZL, where it increased throughout the sampling period (Table 2). The LAI was generally highest in the variety SUWAN-I-Y at $53,60,67$, 74,81 and 88 days after planting. However, the highest
LAl of 1.59 was recorded in the variety ACROSS-97 TZL at 95 DAP. The early application of fertilizer resulted in a higher LAI than the late application (Table 2). There was no significant interaction of variety and time of fertilizer application on leaf area index. 
Table 2: Effects of variety and time of fertilizer application on leaf area index at different stages of growth of maize during the 2006 planting season

\section{DAYS AFTER PLANTING}

\begin{tabular}{|c|c|c|c|c|c|c|c|}
\hline VARIETY & 53 & 60 & 67 & 74 & 81 & 88 & 95 \\
\hline SUWAN-1-Y & 0.80 & 1.18 & 1.40 & 1.55 & 1.57 & 1.47 & 1.57 \\
\hline TZSR-Y & 0.74 & 1.08 & 1.35 & 1.52 & 1.52 & 1.42 & 1.55 \\
\hline DMESR-W & 0.72 & 1.08 & 1.30 & 1.40 & 1.45 & 1.38 & 1.52 \\
\hline ACROSS-97 TZL & 0.72 & 1.07 & 1.22 & 1.39 & 1.32 & 1.34 & 1.59 \\
\hline $\operatorname{LSD}(0.05)$ & 0.12 & 0.14 & 0.22 & 0.12 & 0.12 & 0.14 & 0.12 \\
\hline $\begin{array}{c}\text { Appl. Time (WAP)* } \\
2\end{array}$ & 0.83 & 1.11 & 1.35 & 1.48 & 1.49 & 1.41 & 1.55 \\
\hline 4 & 0.71 & 1.11 & 1.31 & 1.47 & 1.48 & 1.41 & 1.57 \\
\hline 6 & 0.70 & 1.08 & 1.28 & 1.44 & 1.39 & 1.39 & 1.56 \\
\hline $\operatorname{LSD}_{(0.05)}$ & 0.10 & 0.13 & 0.19 & 0.14 & 0.10 & 0.13 & 0.12 \\
\hline
\end{tabular}

Mid-tasselling: The highest number of days to midtasselling (101 days) was observed in the variety ACROSS-97 TZL and this differed significantly $(P<0.05)$ from the variety DMESR-W (89 days) (Table 3 ). The number of days to mid-tasselling decreased with delay in fertilizer application at 6 weeks after planting. The differences $(P<0.05)$ were, however, not significant (Table $3)$.

Mid-silking: The variety DMESR-W attained mid-silking at 107 days after planting, which was earlier than when the variety SUWAN-I-Y (122 DAP) attained mid-silking (Table
3). Like mid-tasselling, the number of days to mid-silking decreased with delay in fertilizer application at 6 WAP but the differences were not significantly $(\mathrm{P}<0.05)$ different (Table 3).

Height of plant at harvest: The height of plants in the variety SUWAN-I-Y $(145.8 \mathrm{~cm})$ was significantly higher than in the variety DMESR-W with a mean height of 132.4 $\mathrm{cm}$. The mean height of plants in the varieties ACROSS$97 \mathrm{TZL}(143.8 \mathrm{~cm})$ and TZSR-Y $(137.6 \mathrm{~cm})$ did not differ significantly

(Table 
Table 3: Effects of variety and time of fertilizer application on number of days to $50 \%$ tasselling, $50 \%$ silking and plant height of four maize varieties during the 2006 planting season

\begin{tabular}{|c|c|c|c|}
\hline Variety & $50 \%$ Tasselling & $50 \%$ Silking & $\begin{array}{l}\text { Plant Height } \\
\text { (cm) }\end{array}$ \\
\hline SUWAN-1-Y & 98.78 & 122.25 & 145.75 \\
\hline TZSR-Y & 95.50 & 116.62 & 137.55 \\
\hline DMESR-W & 89.40 & 107.13 & 132.48 \\
\hline ACROSS-97 TZL & 101.03 & 115.28 & 143.75 \\
\hline $\operatorname{LSD}(0.05)$ & 7.75 & 11.84 & 10.18 \\
\hline $\begin{array}{l}\text { Appl. Time (WAP) } \\
2\end{array}$ & 96.88 & 117.25 & 141.50 \\
\hline 4 & 96.46 & 115.38 & 140.64 \\
\hline 6 & 95.15 & 113.34 & 137.51 \\
\hline $\operatorname{LSD}_{(0.05)}$ & 6.71 & 10.26 & 10.18 \\
\hline
\end{tabular}

Number of sterile plants per plot: A significantly higher number of sterile plants was produced in the variety DMESR-W (0.27) than in the variety SUWAN-I-Y (0.19) (Table 4). The time of fertilizer application did not significantly affect the number of barren plants per plot (Table 4).

Number of ears per plant: The mean number of ears per plant (0.81) in the variety SUWAN-I-Y was significantly $(P<0.05)$ higher than the mean value $(0.73)$ in the variety DMESR-W (Table 4). The delay in the application of fertilizer at 6 WAP did not significantly affect the number of ears per plant.
Ear length: The mean value of ear length was highest in the variety SUWAN-1-Y $(13.55 \mathrm{~cm})$ and lowest in the variety DMESR-W $(12.79 \mathrm{~cm})$ and the difference was significant $(P<0.05)$. The application of fertilizer at 2 WAP resulted in a mean ear length of $13.86 \mathrm{~cm}$, which differed significantly $(P<0.05)$ from the mean ear length of 12.93 $\mathrm{cm}$ when fertilizer was applied at 6 WAP (Table 4).

Ear width: The mean value of ear width was highest in the variety SUWAN-1-Y $(13.95 \mathrm{~cm})$ and lowest in the variety DMESR-W $(12.79 \mathrm{~cm})$ and the difference was significant $(P<0.05)$. The application of fertilizer at 2 WAP resulted in the mean ear width of $13.76 \mathrm{~cm}$, which differed significantly from the mean ear width of $13.24 \mathrm{~cm}$, when fertilizer was applied at 6 WAP (Table 4). 
Table 4: Number of sterile plants per plot, number of ears per plant, ear-length and ear-width in maize during the 2006 planting season

\begin{tabular}{|c|c|c|c|c|c|}
\hline Variety & $\begin{array}{l}\text { No. of } \\
\text { plants }\end{array}$ & barren & No. of ears per plant & $\begin{array}{l}\text { Ear-length } \\
\text { (cm) }\end{array}$ & $\begin{array}{l}\text { Ear-width } \\
(\mathrm{cm})\end{array}$ \\
\hline SUWAN-1-Y & 0.19 & & 0.81 & 13.55 & 13.95 \\
\hline TZSR-Y & 0.22 & & 0.78 & 13.18 & 13.79 \\
\hline DMESR-W & 0.27 & & 0.73 & 12.79 & 12.99 \\
\hline ACROSS-97 TZL & 0.23 & & 0.77 & 13.49 & 13.19 \\
\hline $\operatorname{LSD}_{(0.05)}$ & 0.08 & & 0.08 & 1.64 & 1.12 \\
\hline $\begin{array}{c}\text { Appl. Time (WAP)* } \\
2\end{array}$ & 0.22 & & 0.78 & 13.86 & 13.76 \\
\hline 4 & 0.23 & & 0.77 & 12.98 & 13.43 \\
\hline 6 & 0.24 & & 0.76 & 12.93 & 13.24 \\
\hline $\operatorname{LSD}_{(0.05)}$ & 0.07 & & 0.07 & 1.42 & 0.97 \\
\hline
\end{tabular}

Number of rows per ear: The mean number of rows per ear in the variety SUWAN-I-Y (13.67) was significantly higher $(P<0.05)$ than the values in the varieties ACROSS 97 TZL (12.50) and DMESR-W (11.45). The early application of fertilizer at 2 WAP or late application at 6 WAP did not significantly $(P<0.05)$ affect the number of rows per ear (Table 5). The interaction of variety and time of fertilizer application on the number of rows per ear was observed to be significant. Except for the variety TZSR-Y, the number of rows per ear decreased with delay in the fertilizer application at 4 or 6 WAP (Table 6).

Table 5: Effects of variety and time of fertilizer application on number of rows per ear, number of kernels per row, earweight, shelling percentage, one thousand-kernel weight and total grain yield of maize during the 2006 planting season
Variety
No. of
No. of
Mean ear
weight (g)
(g)
yield $\left(\mathrm{t} \mathrm{ha}^{-1}\right)$

\begin{tabular}{|c|c|c|c|c|c|c|}
\hline $\begin{array}{l}\text { SUWAN-1-Y } \\
\text { TZSR-Y } \\
\text { DMESR-W } \\
\text { ACROSS-97 TZL }\end{array}$ & $\begin{array}{l}13.67 \\
13.27 \\
11.45 \\
12.50\end{array}$ & $\begin{array}{l}30.28 \\
27.79 \\
25.93 \\
27.67\end{array}$ & $\begin{array}{l}62.17 \\
54.67 \\
46.33 \\
52.17\end{array}$ & $\begin{array}{l}77.34 \\
74.82 \\
75.83 \\
72.03\end{array}$ & $\begin{array}{l}149.17 \\
141.67 \\
114.17 \\
140.00\end{array}$ & $\begin{array}{l}4.93 \\
3.65 \\
2.60 \\
3.53\end{array}$ \\
\hline $\operatorname{LSD}(0.05)$ & 0.74 & 3.95 & 11.66 & 5.51 & 36.51 & 1.06 \\
\hline $\begin{array}{c}\text { Appl. Time (WAP) } \\
2 \\
4 \\
6\end{array}$ & $\begin{array}{l}12.93 \\
12.70 \\
12.54\end{array}$ & $\begin{array}{l}30.53 \\
27.16 \\
26.06\end{array}$ & $\begin{array}{l}56.00 \\
55.63 \\
49.88\end{array}$ & $\begin{array}{l}77.68 \\
75.14 \\
72.19\end{array}$ & $\begin{array}{l}141.25 \\
135.00 \\
122.50\end{array}$ & $\begin{array}{l}3.93 \\
3.60 \\
3.53\end{array}$ \\
\hline $\operatorname{LSD}(0.05)$ & 0.64 & 3.42 & $\begin{aligned} & 10.10 \\
= & \text { Week }\end{aligned}$ & $\begin{array}{l}4.77 \\
\text { ter Plan }\end{array}$ & 31.62 & 0.92 \\
\hline
\end{tabular}


Table 6: Effects of variety and time of fertilizer application on number of rows per ear of maize during the 2006 planting

\begin{tabular}{cllccc}
\hline Appl. Time(WAP) & \multicolumn{7}{c}{ SUWAN-1-Y } & TZSR-Y & DMESR-W & ACROSS-97 TZL & Mean \\
\hline 2 & 55.80 & 48.20 & 50.60 & 52.20 & 12.93 \\
4 & 55.40 & 56.00 & 40.61 & 51.20 & 12.70 \\
6 & 52.80 & 55.00 & 46.20 & 46.60 & 12.54 \\
Mean & 13.67 & 13.27 & 11.45 & 12.50 & \\
\hline \multicolumn{5}{c}{ LSD (o.05) Variety (V) $=0.74$} \\
& Application Time (TA) $=0.64$ \\
V X TA =1.28
\end{tabular}

Number of kernels per row: The mean number of kernels per row in the variety SUWAN-1-Y (30.28) was significantly $(P<0.05)$ higher than the value of variety DMESR-W (25.93). The mean values of the number of kernels per row in the variety TZSR-Y (27.79), ACROSS97 TZL (27.67) and DMESR-W (25.93) were statistically similar (Table 5). The application of fertilizer at 2 WAP resulted in the mean number of kernels per row (30.53) which was significantly $(P<0.05)$ higher than when the fertilizer was applied at 6 WAP, with a mean value of 26.06 (Table 5).
Ear weight: The mean values of ear weight in the varieties SUWAN-1-Y (62.17g), TZSR-Y (54.67g), ACROSS-97 TZL (52.17g) and DMESR-W (46.33g) were statistically similar $(P<0.05)$. The mean ear weight was similar irrespective of the time of fertilizer application (Table 5). The interaction of variety and time of fertilizer application on ear weight was significant (Table 7). In the varieties SUWAN-I-Y and DMESR-W, the ear weight decreased with delay in the application of fertilizer at 6 WAP. However, in the varieties TZSR-Y and ACROSS-97 TZL the highest ear weight was observed when fertilizer was applied at 4 and 6 weeks after planting.

Table 7: Effects of variety and time of fertilizer application on ear-weight of maize during the 2006 planting season

\begin{tabular}{|c|c|c|c|c|c|}
\hline Appl. Time(WAP)* & SUWAN-1-Y & TZSR-Y & DMESR-W & ACROSS-97 TZL & Mean \\
\hline 2 & 310.00 & 192.00 & 202.00 & 192.00 & 56.00 \\
\hline 4 & 278.00 & 256.00 & 186.00 & 170.00 & 55.63 \\
\hline 6 & 158.00 & 208.00 & 168.00 & 264.00 & 49.88 \\
\hline Mean & 62.17 & 54.67 & 46.33 & 52.17 & \\
\hline \multicolumn{6}{|c|}{$\begin{array}{c}\text { LSD }(0.05) \text { Variety }(\mathrm{V})=11.66 \\
\text { Application Time }(\mathrm{TA})=10.10 \\
\text { V X TA }=20.20 \\
\text { *WAP = Weeks After Planting }\end{array}$} \\
\hline
\end{tabular}

Shelling percentage: The shelling percentage in varieties SUWAN-I-Y (77.3\%), DMESR-W (75.8\%), TZSR-Y (74.8\%) and ACROSS-97 TZL (73\%) were similar. The delay (6 WAP) in fertilizer application resulted in a significantly lower shelling percentage than the earlier application, (Table 5).

A significant interaction of variety and time of fertilizer application was observed on the shelling percentage, (Table 8). The shelling percentage of varieties
SUWAN-I-Y (268.1\%) and ACROSS-97 TZL (280.4\%) decreased with delay in fertilizer application at 6 WAP, whereas in the variety TZSR-Y, the highest shelling percentage $(320.8 \%)$ was observed when fertilizer was applied at 6 WAP indicating that delay in fertilizer application resulted in an increase in shelling percentage. In the variety DMESR-W, shelling percentage (314.7\%) was highest when fertilizer was applied at 4 WAP.

Table 8: Effects of variety and time of fertilizer application on shelling percentage of maize during the 2006 planting season

\begin{tabular}{clllll}
\hline Appl. Time(WAP) & SUWAN-1-Y & TZSR-Y & DMESR-W & ACROSS-97 TZL & Mean \\
\hline 2 & 336.84 & 296.21 & 309.39 & 300.42 & 77.68 \\
4 & 323.19 & 280.82 & 314.72 & 283.56 & 75.14 \\
6 & 268.05 & 320.78 & 285.89 & 280.39 & 72.19 \\
Mean & 77.34 & 74.82 & 75.83 & 72.00 & \\
\hline
\end{tabular}

LSD (0.05) Variety $(\mathrm{V})=5.51$

Application Time $(\mathrm{TA})=4.77$

VXTA $=9.54$ 
One thousand kernel weight: Irrespective of variety or time of fertilizer application, the one-thousand kernel weight was statistically similar among the varieties throughout the study period, (Table 5). The interaction of variety and time of fertilizer application on one thousand kernel weight was observed to be significant $(P<0.05)$, (Table 9). In the variety SUWAN-I-Y, the kernel weight (620.0g) increased with delay (6 WAP) in fertilizer application, whereas in the varieties DMESR-W and ACROSS-97 TZL, the hightest kernel weights of $530.0 \mathrm{~g}$ and $650.0 \mathrm{~g}$ ), respectively, were observed when fertilizer was applied at 4 WAP. In the variety TZSR-Y, kernel weight $(800.0 \mathrm{~g})$ was hightest when fertilizer was applied at 2 WAP, (Table 9).

Table 9: Effects of variety and time of fertilizer application on one thousand-kernel of maize during the 2006 planting season

\begin{tabular}{|c|c|c|c|c|c|}
\hline Appl. Time(WAP)* & SUWAN-1-Y & TZSR-Y & DMESR-W & ACROSS-97 TZL & Mean \\
\hline 2 & 570.00 & 800.00 & 450.00 & 440.00 & 141.25 \\
\hline 4 & 600.00 & 380.00 & 530.00 & 650.00 & 135.00 \\
\hline 6 & 620.00 & 520.00 & 390.00 & 590.00 & 132.50 \\
\hline Mean & 149.17 & 141.67 & 114.17 & 140.00 & \\
\hline & \multicolumn{5}{|c|}{$\begin{array}{c}\text { LSD }(0.05) \text { Variety }(\mathrm{V})=36.51 \\
\text { Application Time }(\mathrm{TA})=31.62 \\
V \times \text { TA }=63.23 \\
\text { *WAP = Weeks After Planting }\end{array}$} \\
\hline
\end{tabular}

Total grain yield: The variety SUWAN-I-Y produced the highest total grain yield of $4.9 \mathrm{t} \mathrm{ha}^{-1}$, which differed significantly $(P<0.05)$ from those of the varieties DMESRW (2.6 t ha $\left.{ }^{-1}\right)$ and ACROSS-97 TZL (3.5 $\left.\mathrm{t} \mathrm{ha}^{-1}\right)$. Total grain yield was similar irrespective of the time of fertilizer application, (Table 5).

\section{DISCUSSION}

In a crop such as maize, leaf growth has been reported to be completed in about 60 days after planting (Samuel and Werner, 1978). In this study, the numbers of leaves per plant increased with crop age up to 81 DAP and thereafter decreased across the varieties and time of fertilizer application. This indicates a change from vegetative phase to reproductive phase. Similarly, the leaf area index, which measures the leafiness of the plant, increased with crop age up to 81 DAP and then decreased across varieties and time of fertilizer application. This shows that the maize crop does not continue to produce leaves throughout its life span; growth ceases after the formation of the male inflorescence. At the early stages of growth, the roots are still young and very active to allow the movement of nutrients through the roots to the leaves. The early application of fertilizer enhanced efficient leaf production and hence leaf area index. Samuel and Werner (1978) recommended the early application of fertilizer to the young plants in order to promote early growth and formation of large, healthy leaves.

In most crop plants, growth and development proceed in two major phases (the vegetative and the reproductive phases). The reproductive or flowering phase starts after the completion of vegetative phase. The early application of fertilizer enhances leaf-growth, thus making enough assimilates available to be transferred to the sink (grains) at a later stage of the crop growth. In this study, the application of fertilizer at 2 WAP hastened tesselling and silking (reproductive phase) which translated into higher grain yield.

\section{CONCLUSION}

This study shows that yield advantages were gained by cultivating maize with early fertilizer application. An estimated value of $3.93 \mathrm{t} \mathrm{ha}^{-1}$ was recorded for grain yield at 2 WAP. With the present high cost of inorganic fertilizer, which is largely unaffordable and unavailable to peasant farmers, the yield potential by farmers in this study area can be maximized and improved by early fertilizer application in the Jos-Plateau environment.

\section{REFERENCES}

Adediran, J. A and Banjoko, V. A., 2003. Comparative Effectiveness of Some Compost Fertilizer Formulation for Maize In Nigeria. Nigerian Journal of Soil Science, (13): 42-48.

AERLS., 1987. Maize Production in Northern States of Nigeria. Agricultural Extension, Research and Liaison Services. Extension Bulletin, No. (11): 574.

Awotundun, J. S., Bandele, M. T and Aminu, A., 1994. Effects of Different Levels of Nitrogen Fertilizer on the Yield of Hybrid Maize. Nigerian journal of Botany, (7): 39-44.

Daramola, A. M., 1991. Post-harvest grain loss and evaluation of grain smoking for the control of storage insect pests of maize. National Farm System Network, Ibadan. PP 109-117.

Egharevba, P. N., Horrocks, R. S and Zuber, M. S., 1976. 
Dry matter accumulation in maize in response to defoliation. Agronomy Journal, (68): 40-43.

Fashina, A. S., 2000. Basic Principles in Field Experimentation and Data Analysis for Tertiary Institutions in Nigeria. Minerib Record Limited, Mushin, Lagos. 111pp.

Fashino, A. S., Olatunji, K. A and Alsiri, K. O., 2002. Effects of Different Plant Populations and Poultry Manure on Yield of "Ugu" (Telfaria occidentalis) in Lagos State, Nigeria. Proceedings of the Annual Conference of Horticultural Society of Nigeria. PP. 123-127.

Idachaba, F. S., 1994. Plants for Nigerians: Report on Central Zone. National Agricultural Research Project, Department of Agricultural Science, Federal Ministry of Agriculture and Natural Resources, Lagos, PP. 117-118.

Kolawole, E. L and Joyce, E. L., 2009. The Performance of Zea mays as Influenced by NPK Fertilizer Application. Not Sci Biol 1, (1): 59-62.

Lucy, B., James, D. C and Jimmy, J., 1998. Arizona Master Gardener Manual. Arizona Co-operative Extension, College of Agriculture, University of Arizona.http://ag.arizon.edu/pubs/gardeb/mg/intro. $\underline{\mathrm{html}}$.
Obi, C. O., Nnabule, P. C and Onucha, E., 2005. Effect of Kitchen Waste Compost and Tillage on Soil Chemical Properties and Yield of Okra (Abelmoschus esculentus). Soil Science, (15): 6976.

Olaoye, G and Adegbesen, O. N., 1991. Utilization and Processing of Maize. IITA Research Guide No. 35. Training Program, International Institute of Tropical Agriculture (IITA) Pp29.

Samuel, T and Werner, N., 1978. Soil Fertility and Fertilizer, $3^{\text {rd }}$ edition. John Wiley and Sons, New York. 511pp.

Stefano, P., Dris, R and Rapparini, F., 2004. Influence of Growing Conditions on Yield and Quality of Cherry.II Fruit. Journal of Agriculture and Environment, (2): 307-309.

Watson, D. J., 1947. Leaf Growth in Relation to Crop Yield. In: M. L. Milthorpe (ed). The growth of leaves.Butterworths, London. PP. 178-191 